\title{
GEOMETRY GEOMETRIE
}

\section{DESIGN AND RATIONALIZATION}

Starting with the general concept of a reciprocal structural system formed by interlocking linear members, a dynamic form-finding process without a distinct design goal developed that nevertheless led to specific articulations.

Structures were designed in a mutual relationship between detail and spatial configuration, employing the principle of interlocking on both the scale of notched joints as well as the spatial positioning of members. $\nearrow^{14}$ This resulted in frameworks in which the architectural definition of spaces was deeply and inseparably intertwined with the characteristics and constraints of the joint details, which in turn were defined by material logic, establishing a direct relationship between space and material.

In this context, the joining principle not only serves the functional purpose of construction, but it becomes fundamental to architectural organization and articulation.

The workshop results show that although the design had complex characteristics referring to the concept of 'naturalness' (Fig. 1) $\nearrow^{15}$, there was a necessity for an underlying systematic and ordering principles if such structure were to be realized with timber beams. Furthermore, such principles were important to eventually generalize the design to some extent in order to translate the concept to other contexts. In the continuation of the workshop results, these ordering principles were identified and developed. A digitized model of the first Kigumi prototype was the basis for an iterative workflow of rationalization and optimization to this end (Fig. 2). $\nearrow^{16}$

Investigations on form-finding in a digital hanging model for optimizing structural performance not only helped to refine the realized structure, but also led to further digital studies on the relationships between design freedom and geometric constraints, chaos and order, and space-encompassing structures and structurally optimized form (Fig. 3). $\nearrow^{17}$

\section{ENTWURF UND UMSETZUNG}

Ausgehend von einem allgemeinen Konzept eines reziproken Struktursystems aus linearen Stäben entwickelte sich ein dynamischer Formfindungsprozess ohne eindeutiges Entwurfsziel, der jedoch zu spezifischen Ausformungen führte.

Strukturen wurden in einem wechselseitigen Verhältnis von Detail und räumlicher Konfiguration entworfen, wobei das Prinzip des miteinander Verschränkens sowohl auf der Ebene der Uberblattungsverbindungen als auch auf der Ebene der räumlichen Positionierung der Stäbe angewendet wurde. $\nearrow^{14}$ Dies führte zu Konstruktionen, in denen die architektonische Definition von Räumen grundlegend und untrennbar mit den Eigenschaften und Anforderungen der Verbindungsdetails verwoben war, die ihrerseits durch die Logik des Materials definiert waren, wodurch diese Strukturen geprägt waren von einer engen Beziehung zwischen Raum und Material.

In diesem Zusammenhang dient das Verbindungsprinzip nicht nur dem funktionalen Zweck der Konstruktion, sondern es wird zum bestimmenden Faktor für die architektonische Organisation und Ausformung.

Die Ergebnisse des Workshops zeigen, dass, obwohl der Entwurf komplexe Merkmale aufwies, die sich auf das Konzept der ,Natürlichkeit ${ }^{\star}$ (Abb. 1) $\nearrow^{15}$ beziehen, dennoch ein zugrunde liegendes systematisches und ordnendes Prinzip notwendig war, um eine solche Struktur mit Holzstäben realisieren zu können. Darüber hinaus waren solche Prinzipien wichtig, um den Entwurf zu einem gewissen Grad zu verallgemeinern, damit das Konzept auf andere Kontexte übertragen werden kann. In Fortführung der Workshop-Ergebnisse wurden diese Ordnungsprinzipien identifiziert und entwickelt. Ein digitalisiertes Modell des ersten Kigumi-Prototyps war die Grundlage für einen iterativen Arbeitsablauf der Rationalisierung und Optimierung in diesem Sinne (Abb. 2). $\nearrow^{\mathbf{1 6}}$

Untersuchungen zur Formfindung im digitalen Hängemodell zur Optimierung der Tragfähigkeit halfen nicht nur bei der Verfeinerung der realisierten Struktur, sondern führten auch zu weiteren digitalen Studien über die Beziehungen zwischen Gestaltungsfreiheit und geometrischen Zwängen, Chaos und Ordnung sowie raumgreifender Kapazität und strukturell optimierter Form (Abb. 3). $\nearrow^{17}$ 
- Fig. 1| Abb. 1:

Performance artist Daniel Aschwanden interacting with $I S-1$ at the opening of the group exhibition Understanding Artistic Research, MAK, Vienna 2019.

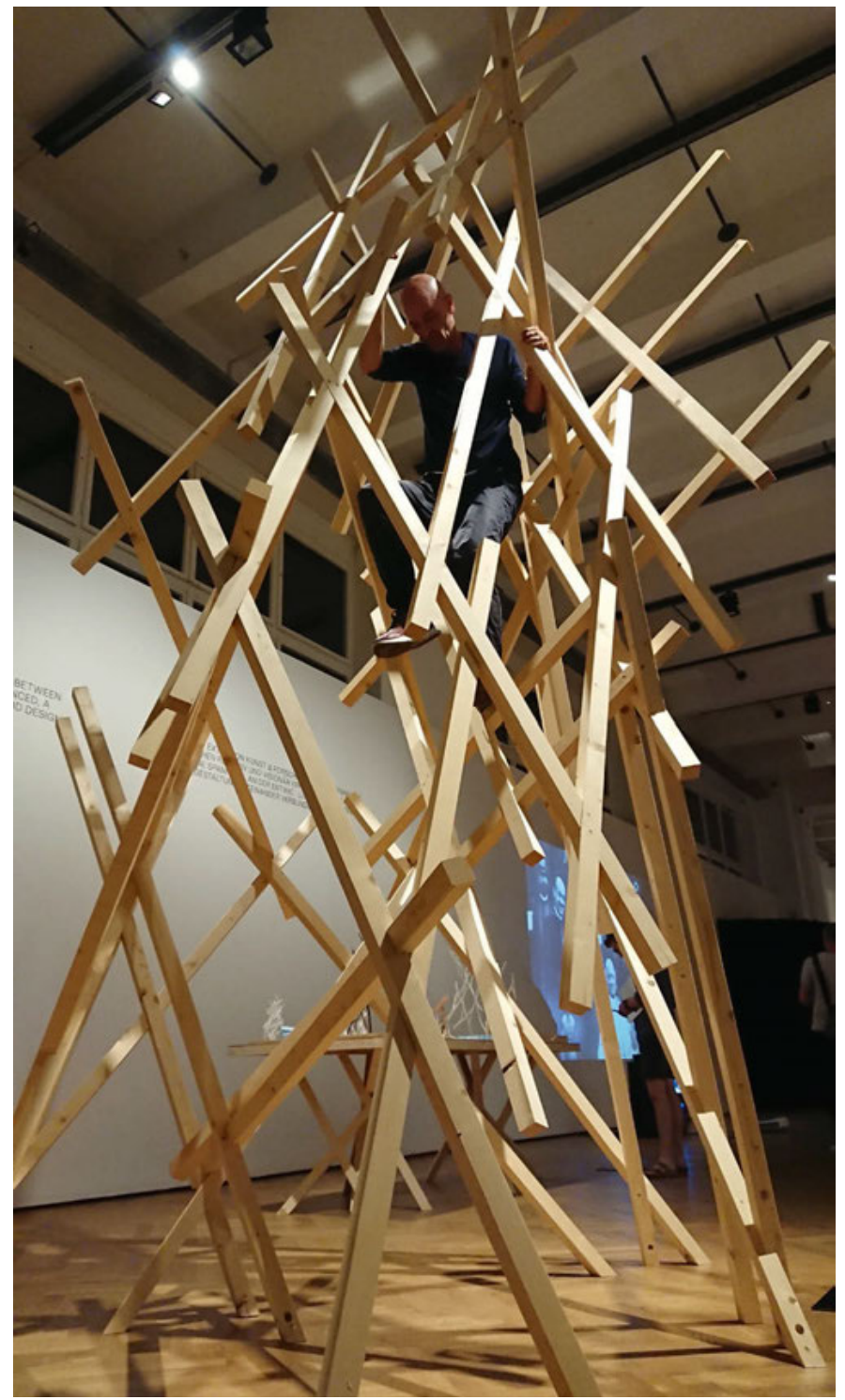

4Fig. 2 | Abb. 2:

3D-printed models (from left to right) of the 3D scan of the analog model form the workshop, a rationalized modification of that configuration with members aligned to as few different vectors as possible and the design of the built structure (IS-1) that balances irregularity and order. 


\section{[2.1] INTERLOCKING SPACES : GEOMETRY}
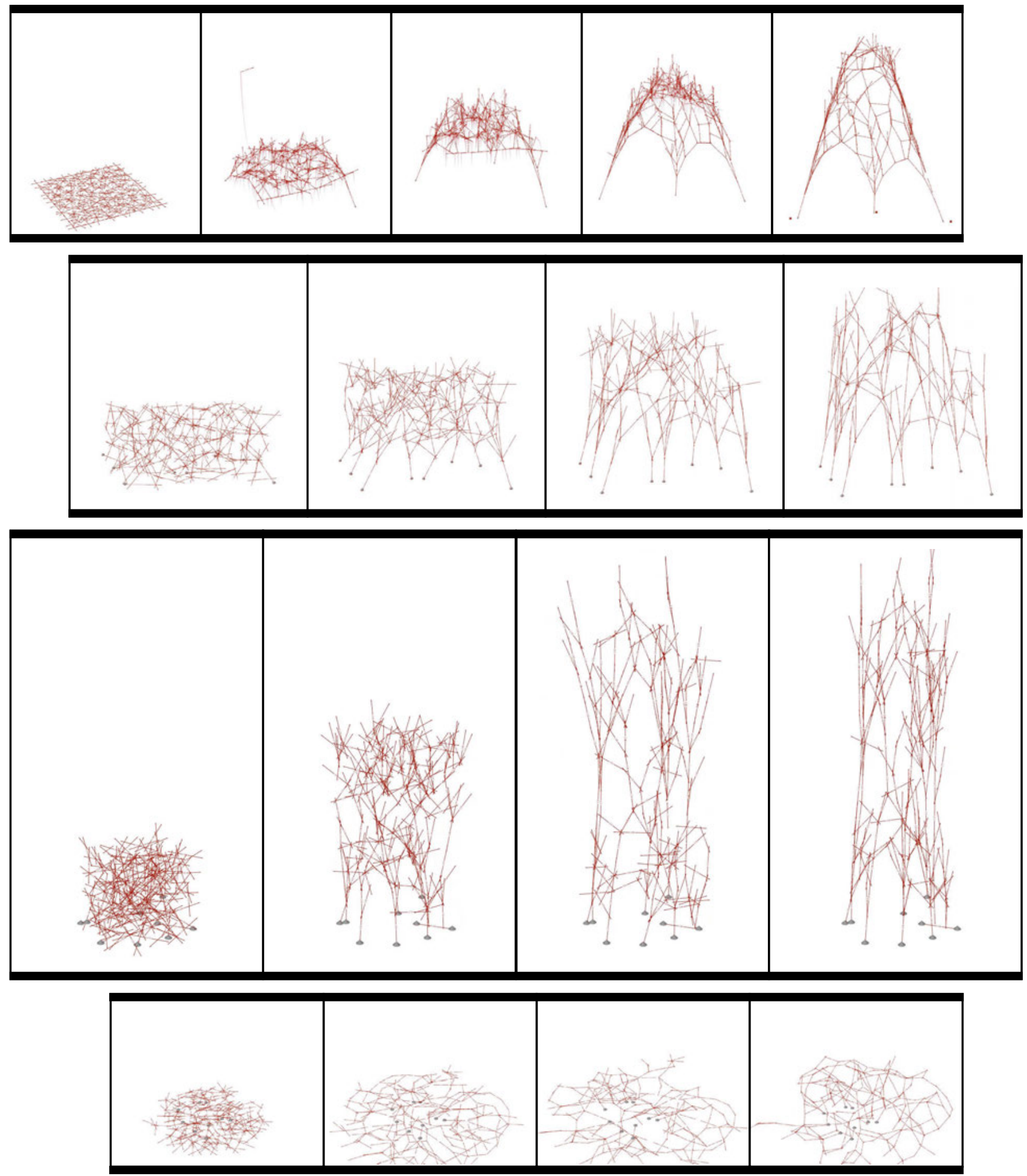

$\Delta$ Fig. 3 | Abb. 3:

Sequences of form-finding studies Kigumi Extended by Adam Orlinski.

Line elements of identical length were arranged into frameworks and tested in

physics simulations with various sets of constraints and forces using Kangaroo3D. 

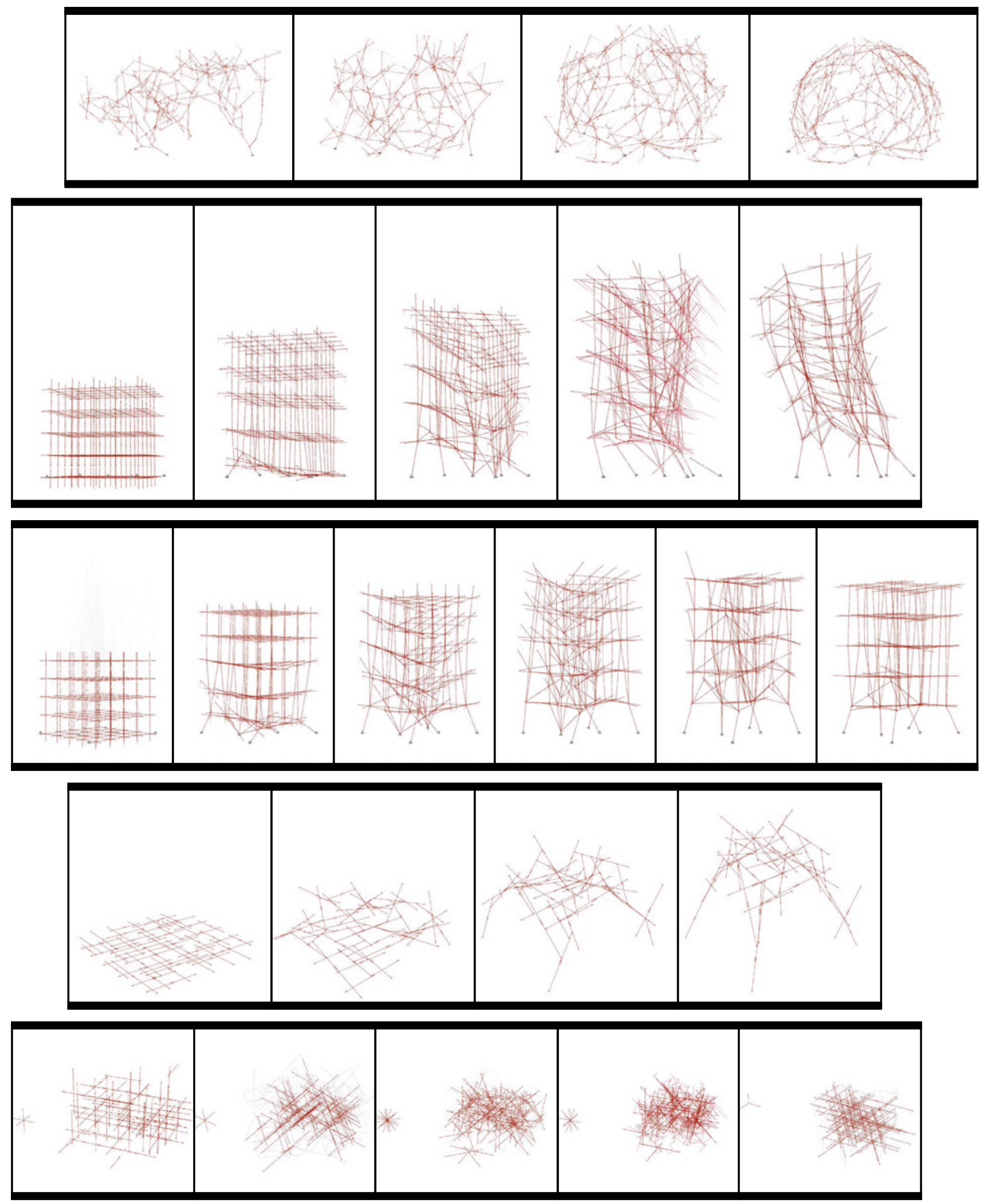


\section{MODULAR SYSTEM}

Subsequent to the realization of the first prototype $I S-1$, the Kigumi system was developed towards modularity with the aim of transforming the singular formation into an adaptive design system. This development started with case studies that investigated an application as tables. At first, a specific subsection of $I S-1$ was identified as a potential frame module (Fig. 4a). The extracted fraction was modified and refined to become a self-standing construction (Fig. 4b) that condensed the structural principles of the reciprocal system (Fig. 5). Two of these modules were combined and expanded by additional beams that support the tabletop, to form a complete structure (Figs. 6a-d). The beams within the modules are organized in two criss-crossing lattice planes. $\nearrow^{18}$

In a further iteration $(T-2 a)$, the table surface was intersected with these planes and partially shifted to differentiate the usable surface into a split-level configuration (Figs. 7a+b). The transcription of a structural principle into the spatial organization and the articulation of usable interfaces affected a blurring of a clear programmatic definition of the architectural scheme. It introduced a level of uncertainty that had the potential to open the palette of use cases. In this latent ambiguity, there is no ideal or optimized inhabitation scenario; rather, the 'diffuse functionality' affords many possible modes of interaction, and a usage must be found in each situation in an active engagement.

Despite shortcomings in terms of structural performance (Fig. 8) and assembly process, this model demonstrated some of these potentials as people interacted with this table (Figs. $9 a+b)$.

Focusing on the structural and geometric development of the Kigumi system, the table study $T-2 b$ was a first test of an interlocking concept that combines beams and surface panels (Figs. 10a $+\mathrm{b}$ ) $\nearrow^{19}$, which was later implemented into the design of the second large-scale installation $I S-2$.

\section{MODULARES SYSTEM}

Im Anschluss an die Realisierung des ersten Prototyps IS-1 wurde das Kigumi-System in Richtung Modularität weiterentwickelt, mit dem Ziel, die singuläre Formation in ein adaptives Designsystem zu transformieren. Diese Entwicklung begann mit Fallstudien, die eine Anwendung für Tische untersuchten. Zunächst wurde ein bestimmter Teilbereich von IS-1 als potenzielles Modul identifiziert (Abb. 4a). Der extrahierte Teilbereich wurde modifiziert und verfeinert, um eine selbsttragende Konstruktion zu werden (Abb. 4b), in der die strukturellen Prinzipien des reziproken Systems verdichtet sind (Abb. 5). Zwei dieser Module wurden kombiniert und durch zusätzliche Stäbe, die die Tischplatte tragen, zu einer kompletten Struktur erweitert (Abb. 6a-d). Die Stäbe innerhalb der Module sind in zwei sich kreuzenden Gitterebenen organisiert. $\nearrow^{18}$

In einer weiteren Iteration der Tischstudien (T-2a) wurde die Tischfläche mit diesen Ebenen verschnitten und teilweise verschoben, um so die Nutzfläche in eine Split-Level-Konfiguration zu differenzieren (Abb. 7a+b). Die Übertragung eines strukturellen Prinzips in die räumliche Organisation und die Ausformung von nutzbaren Oberflächen bewirkten eine Verwischung der programmatischen Definition des architektonischen Schemas. Dies führte zu einer gewissen Unbestimmtheit, die das Potenzial hatte, die Möglichkeiten der Benutzbarkeit zu erweitern. In dieser latenten Unklarheit gibt es kein ideales oder optimiertes Nutzungsszenario, die diffuse Funktionalität bietet vielmehr viele Möglichkeiten der Interaktion, eine Nutzung muss jeweils situationsbezogen in einer aktiven Auseinandersetzung gefunden werden.

Trotz der mangelhaften strukturellen Leistungsfähigkeit (Abb. 8) und des schwierigen Montageprozesses zeigte dieses Modell einige dieser Potenziale, die sichtbar wurden, sobald Menschen mit dem Tisch interagierten (Abb. 9a+b).

Mit dem Fokus auf die strukturelle und geometrische Entwicklung des Kigumi-Systems war die Tischstudie T-2b ein erster Test eines Konzeptes, in dem die zusätzlichen Flächen Teil des konstruktiven Systems werden (Abb. 10a $+\mathrm{b}) \nearrow^{19}$, dieses wurde später im Design der zweiten größeren Installation $I S$-2 übernommen.

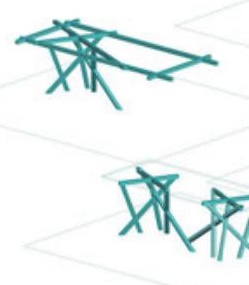




\section{$\mathbb{N}$

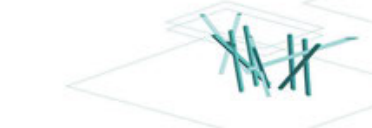

X
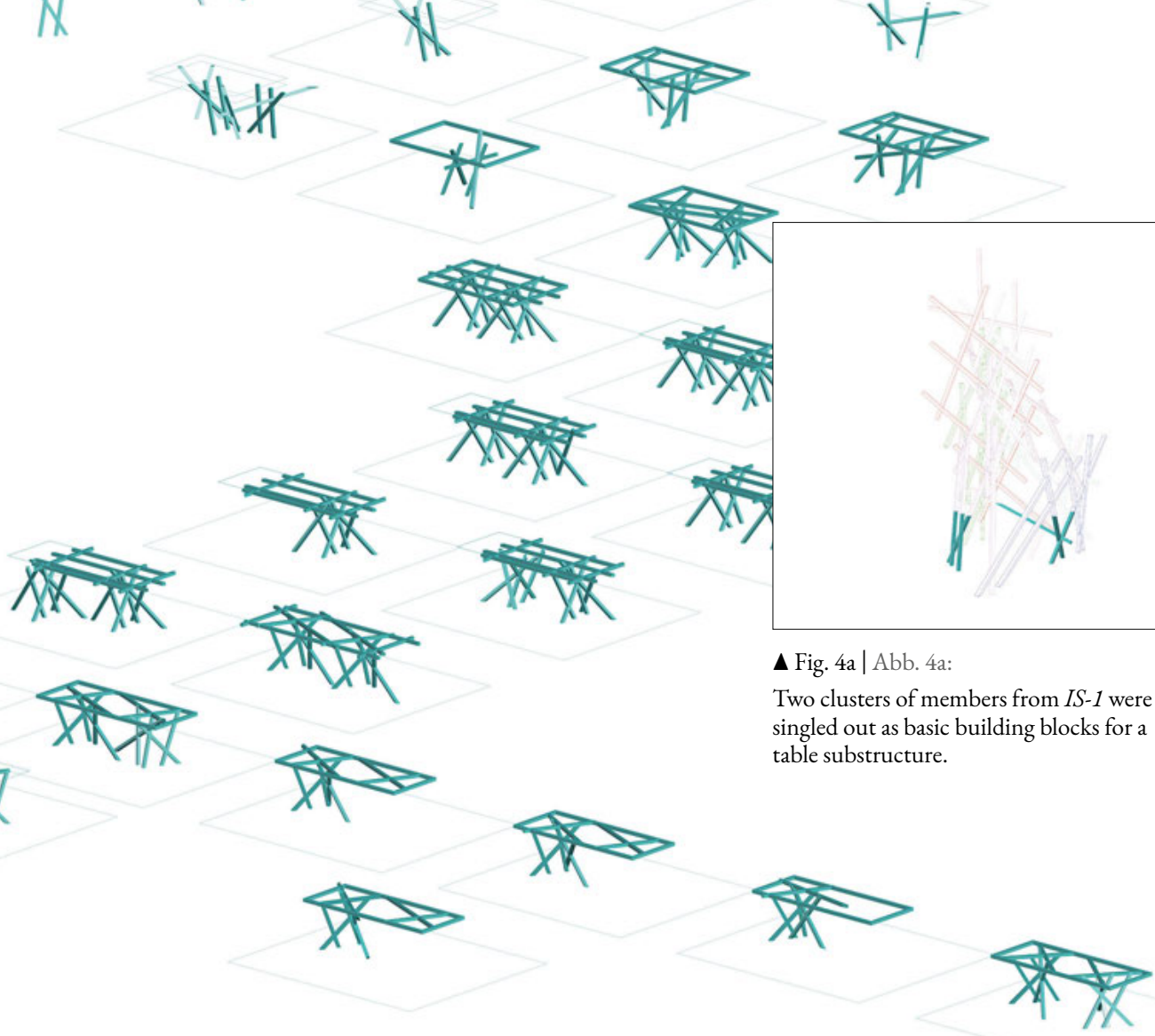

$\Delta$ Fig. 4a | Abb. 4a:

Two clusters of members from $I S-1$ were singled out as basic building blocks for a table substructure.

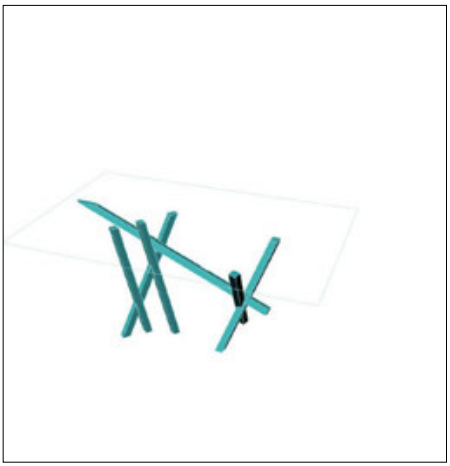

$\Delta$ Fig. 4b | Abb. 4b:

The extracted clusters were combined into one structural module.
4 Fig. 5 | Abb. 5:

Iterations of the development of $T-1$.
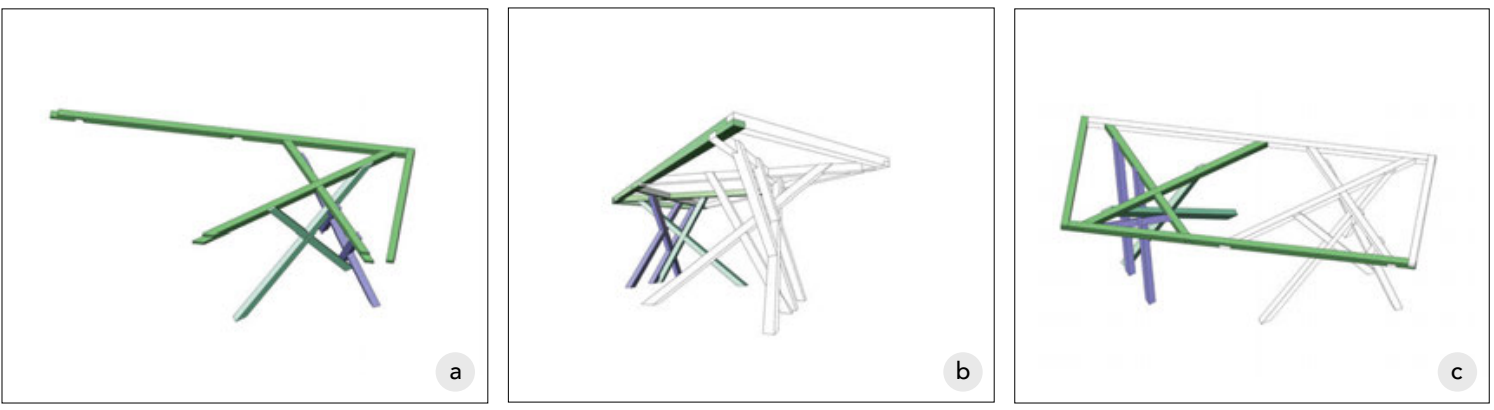

$\boldsymbol{\Delta} \boldsymbol{\Delta} \Delta$ Figs. 6a-c $\mid$ Abb. 6a-c:

A configuration of beams (a) is duplicated and rotated $180^{\circ}(\mathrm{b})$ to form a complete structure (c).

- Fig. 6d|Abb. 6d:

$T-1$ as an exhibition display for models and artifacts from the Conceptual Joining research process at the World Wood Days 2019, Stübing, Austria.

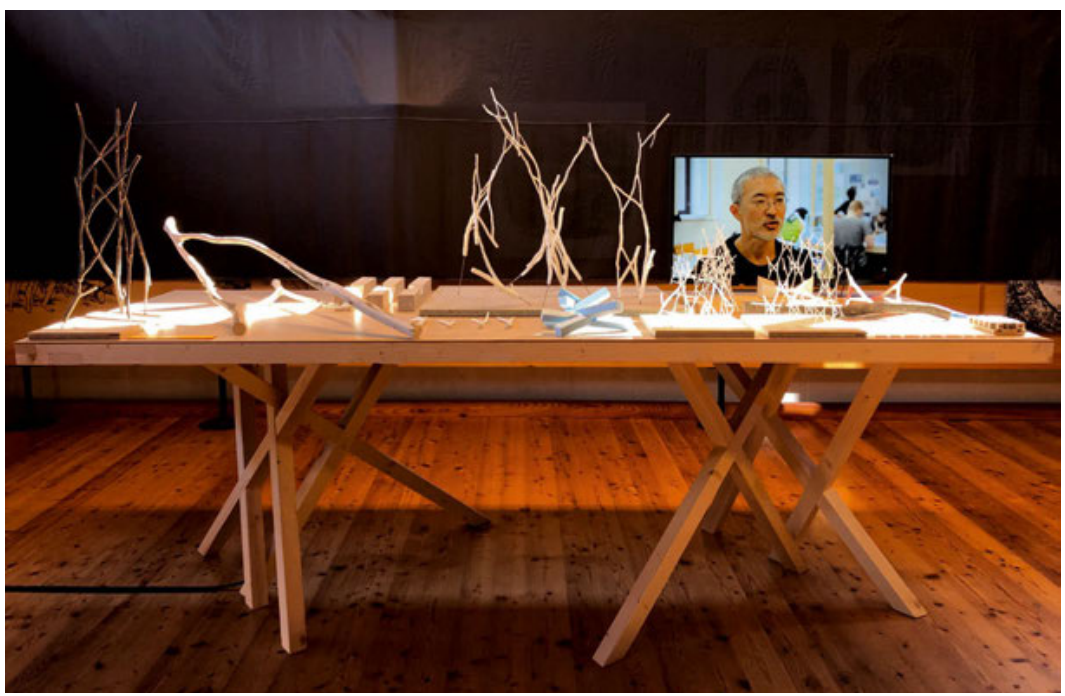




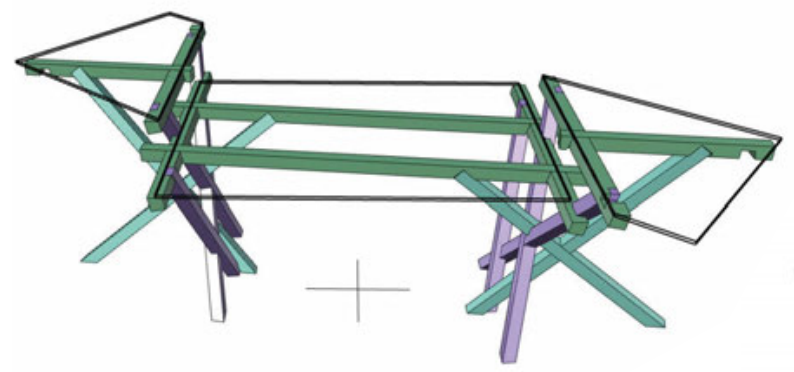

$\Delta$ Fig. 7a | Abb. 7a:

The design of $T-2 a$ employs the same copy-paste principle as in $T-1$.
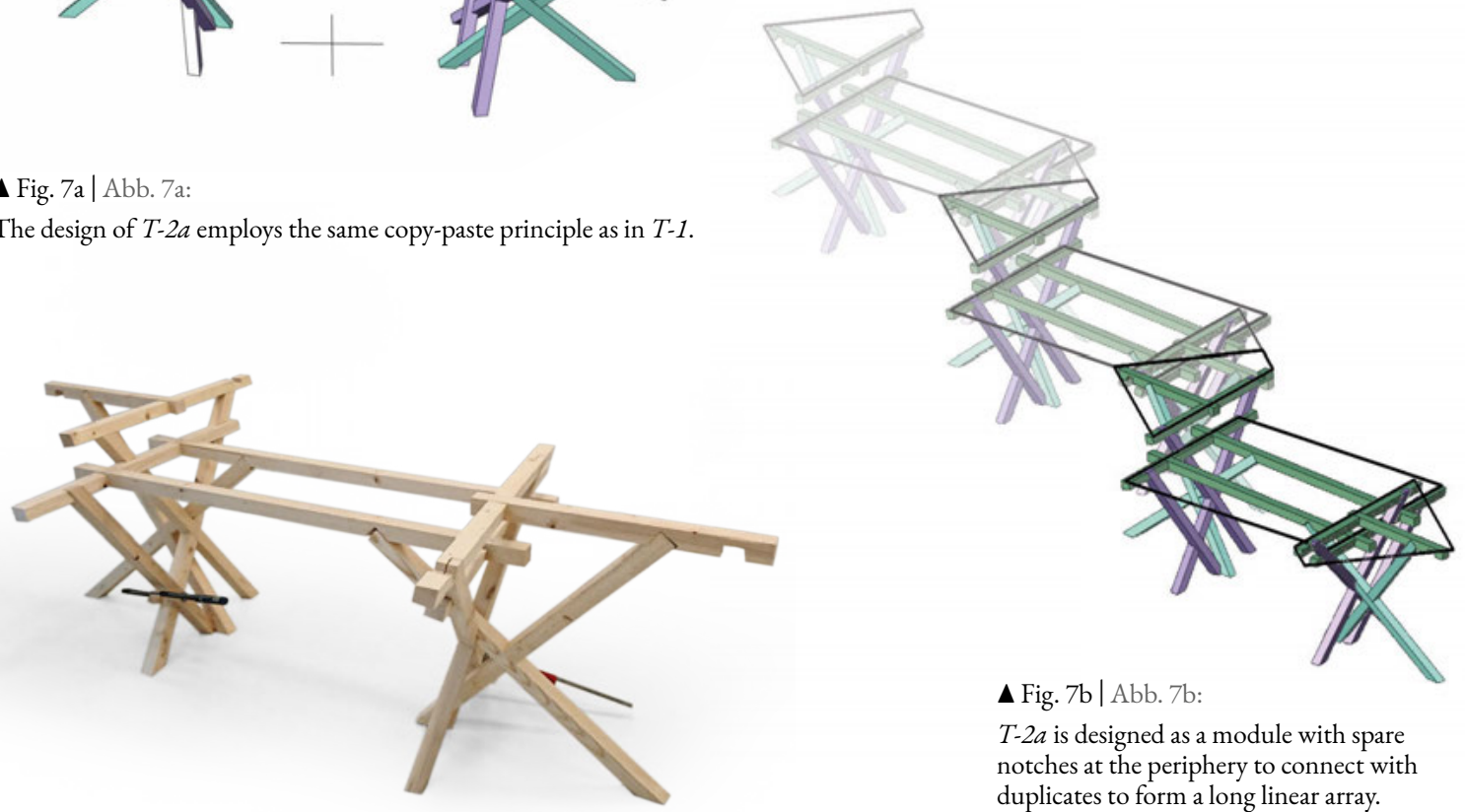

$\Delta$ Fig. 7b | Abb. 7b:

$T-2 a$ is designed as a module with spare notches at the periphery to connect with duplicates to form a long linear array.

$\Delta$ Fig. 8 | Abb. 8:

The splitting of otherwise continuous beams at the top horizontal layer affected a high density of notches where the tabletop splits. As a result, some connections had to be screwed for fixation, furthermore the tabletop panel had to be screwed.

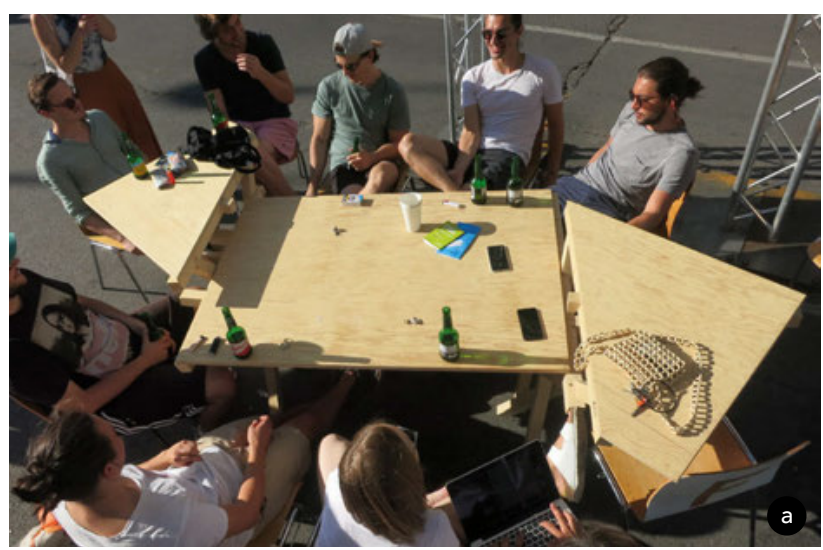

$\Delta$ Figs. $9 \mathrm{a}+\mathrm{b} \mid$ Abb. $9 \mathrm{a}+\mathrm{b}:$

T-2a in use at the Angewandte Festival, Vienna, 2019 (a) and at the Conceptual Joining show at AIL, Vienna, 2019 (b).

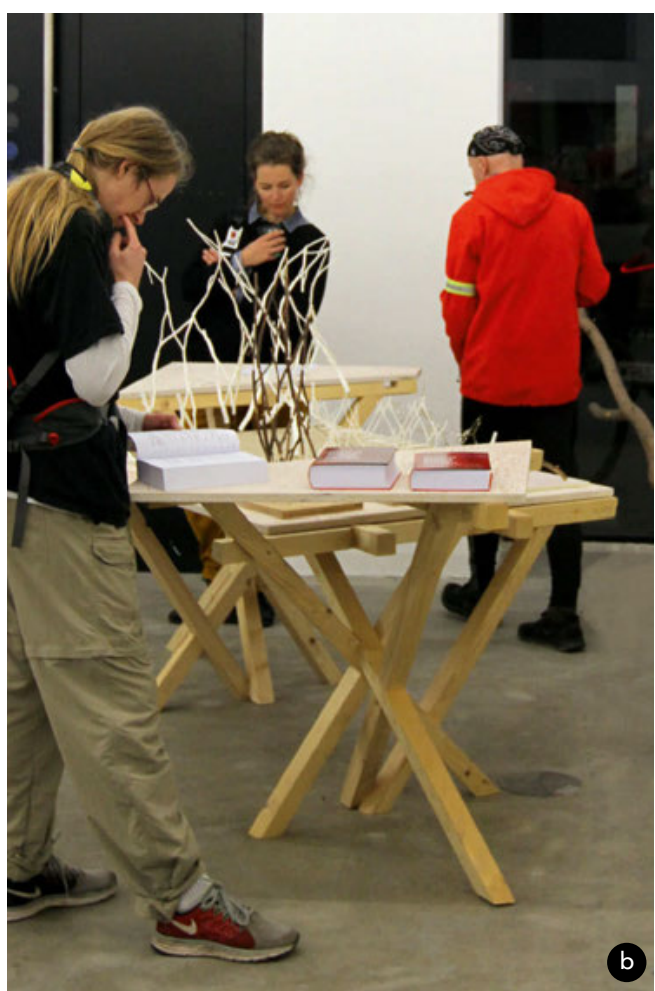




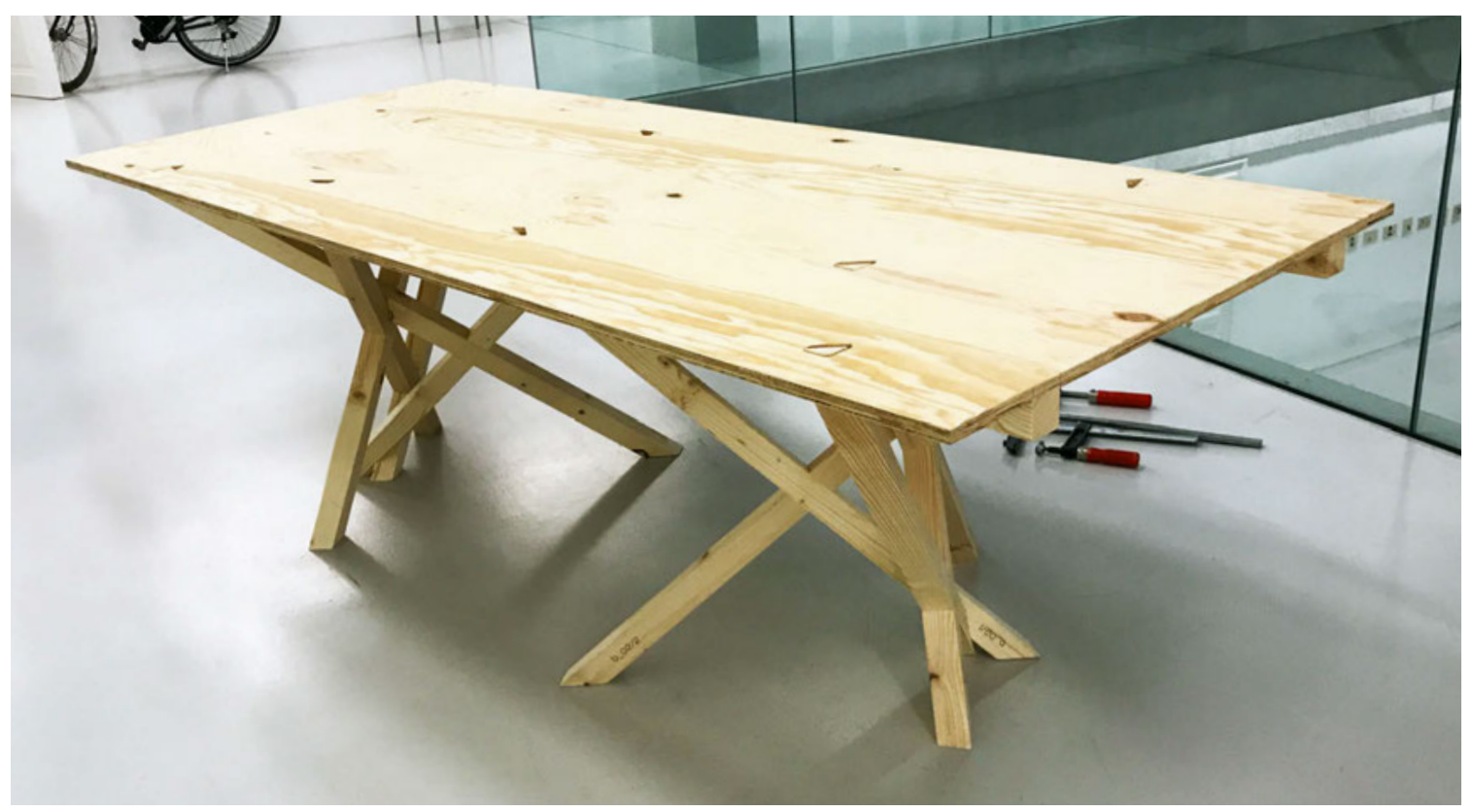

\ Fig. 10a | Abb. 10a:

$T-2 b$ consists of a modification of the beam configuration developed in $T-1$, the tips of the beams slot into holes in the plywood tabletop to stabilize the system without additional fasteners.

V Fig. 10b | Abb. 10b:

$T-3 a$ is a further development of $T-2 b$ with a more slender hard wood structure. Beams in cherry wood, tabletop in birch plywood.

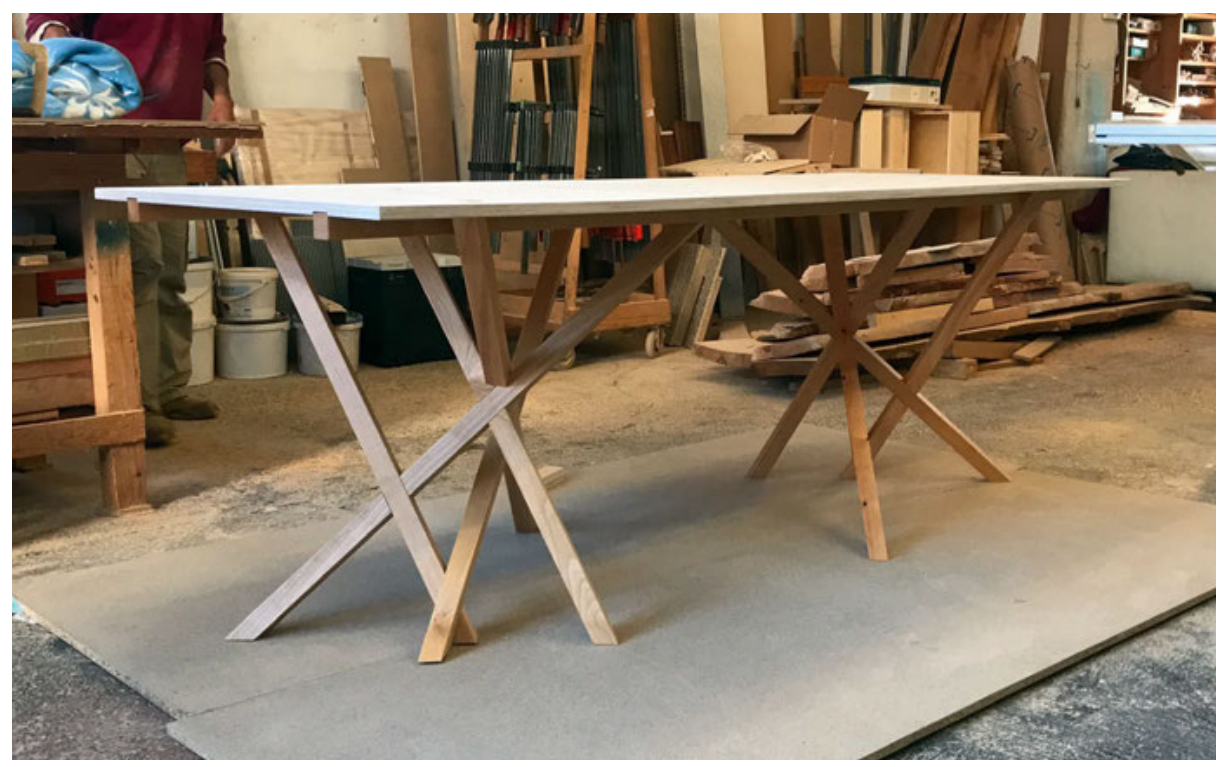




\section{MODULES AND COMPLEXITY}

The modules of the table studies were enlarged and adapted to an architectural setting. Various modular systematics were investigated in digital models, negotiating repetition and diversity and examining the thresholds of design flexibility within structural constraints.

Two concepts of a modular system emerged. One used spatial modules, designed as robust and stable structural units that could be aggregated into a simple logic of linear arrays in $\mathrm{x}$ and $\mathrm{y}$ directions and stacked vertically (Fig. 11).

The other category operated with less rigid, but more versatile components. These could be arranged into a wide variety of configurations using a complex syntax (Fig. 12). For the realization of the $I S-2$ installation, the two systems were combined (Fig. 13) using the advantage of one to compensate for the weakness of the other, merging stability and versatility into a comprehensive version of the Kigumi system (Figs. 14a-c).

The modular design concept manifested itself in aggregations formed by a limited set of part types, each present in multiple instances (Fig. 15). The prefab beam elements were designed with multiple notches to facilitate all possible combinations of modules, which produces a redundancy of joint details that offers a variety of recombinations. $\nearrow^{20}$

The configuration of beams that was realized as $I S-2$ (Fig. 16) was expanded by a set of plywood panels interlocking with the linear members. These surfaces are not part of the modular system but are rather positioned according to local conditions, which adds a layer of design interventions independent from modular constraints. On one hand, they perform as bracing elements to stabilize the overall framework at strategic locations, on the other, they indicate possible use cases and thus refer to an application as part of a building (Fig. 17).

Within the spatial modules (Fig. 14c), beams are positioned using a limited set of angles and distances between them. That is why even though the beam elements were specifically designed for a distinct role and relative position, to some extent, they also had a universal functionality within the modular system. With some limitations, elements could be repositioned or added independently from their prescribed relative location, this provided an additional

\section{MODULE UND KOMPLEXITÄT}

Im weiteren Verlauf wurden die in den Tischstudien entwickelten Module vergrößert und an einen architektonischen Kontext angepasst. Verschiedene Modulsysteme wurden in digitalen Modellen untersucht, wobei Wiederholung und Vielfalt miteinander verhandelt und die Möglichkeiten der gestalterischen Freiheit innerhalb konstruktiver Rahmenbedingungen untersucht wurden.

Es bildeten sich zwei Konzepte eines modularen Systems heraus. Beim einen wurden geräumige Module verwendet, die als robuste und stabile Struktureinheiten konzipiert waren. Diese konnten in einer einfachen Logik von linearen Anordnungen in $\mathrm{x}$ - und $\mathrm{y}$-Richtung zusammengefügt und vertikal gestapelt werden (Abb. 11).

Das andere System arbeitete mit weniger stabilen, aber vielseitigeren Komponenten. Diese konnten mit Hilfe einer komplexen Syntax zu einer Vielzahl von Konfigurationen angeordnet werden (Abb. 12). Für die Realisierung der IS-2Installation wurden diese beiden Systeme schließlich kombiniert (Abb. 13), wobei der Vorteil des einen die Schwäche des anderen ausglich. So konnte eine Version des KigumiSystems umgesetzt werden, die sowohl stabil als auch vielseitig war (Abb. 14a-c).

Das modulare Konstruktionskonzept manifestierte sich in Aggregationen, die aus einem begrenzten Sortiment von Bauteiltypen gebildet wurden, die jeweils in mehreren Ausführungen vorkamen (Abb. 15). Diese vorgefertigten Stabelemente wurden mit mehreren Ausklinkungen versehen, um alle möglichen Kombinationen von Modulen zu berücksichtigen, was zu einer Redundanz der Verbindungsdetails führte. $\nearrow^{20}$

Die als IS-2 realisierte Stabkonstruktion (Abb. 16) wurde durch eine Reihe von Sperrholzplatten erweitert, die mit den linearen Elementen verbunden sind. Diese Flächen sind nicht Teil der modularen Logik, sondern werden entsprechend der jeweiligen lokalen Bedingung positioniert, was zusätzliche, von den Einschränkungen des Modulsystems unabhängige Gestaltungsfreiheiten mit sich bringt. Die Platten fungieren einerseits als aussteifende Elemente, die die Konstruktion an strategischen Stellen stabilisieren, andererseits deuten sie mögliche Nutzungen an und verweisen so auf eine Anwendung als Teil von Gebäuden (Abb. 17).

Innerhalb der Module (Abb. 14c) wurden die Stäbe unter Verwendung einer begrenzten Anzahl von Winkeln und Abständen zueinander positioniert. Daher hatten die Stabelemente, obwohl sie speziell für eine bestimmte Rolle und eine relative Position entworfen wurden, bis zu einem gewissen Grad auch eine universelle Funktionalität innerhalb des 


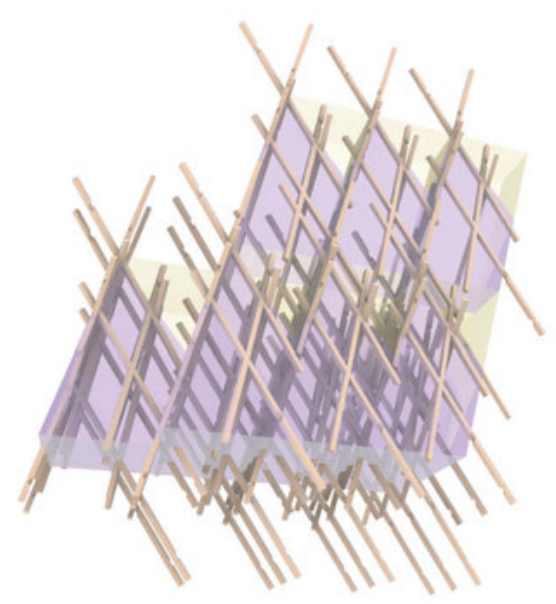

A Fig. $11 \mid$ Abb. 11:

Diagram of a system of identical spatial modules which can be stacked and arrayed.

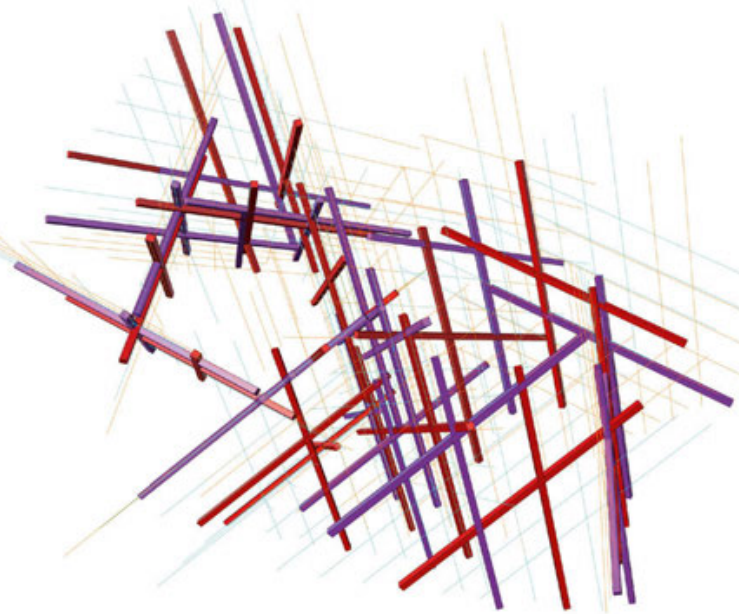

A Fig. 12 | Abb. 12:

Diagram of a possible configuration of a system of two types of spatial modules, which can form a larger module. These modules would not be stable without an assembly of multiple module instances.

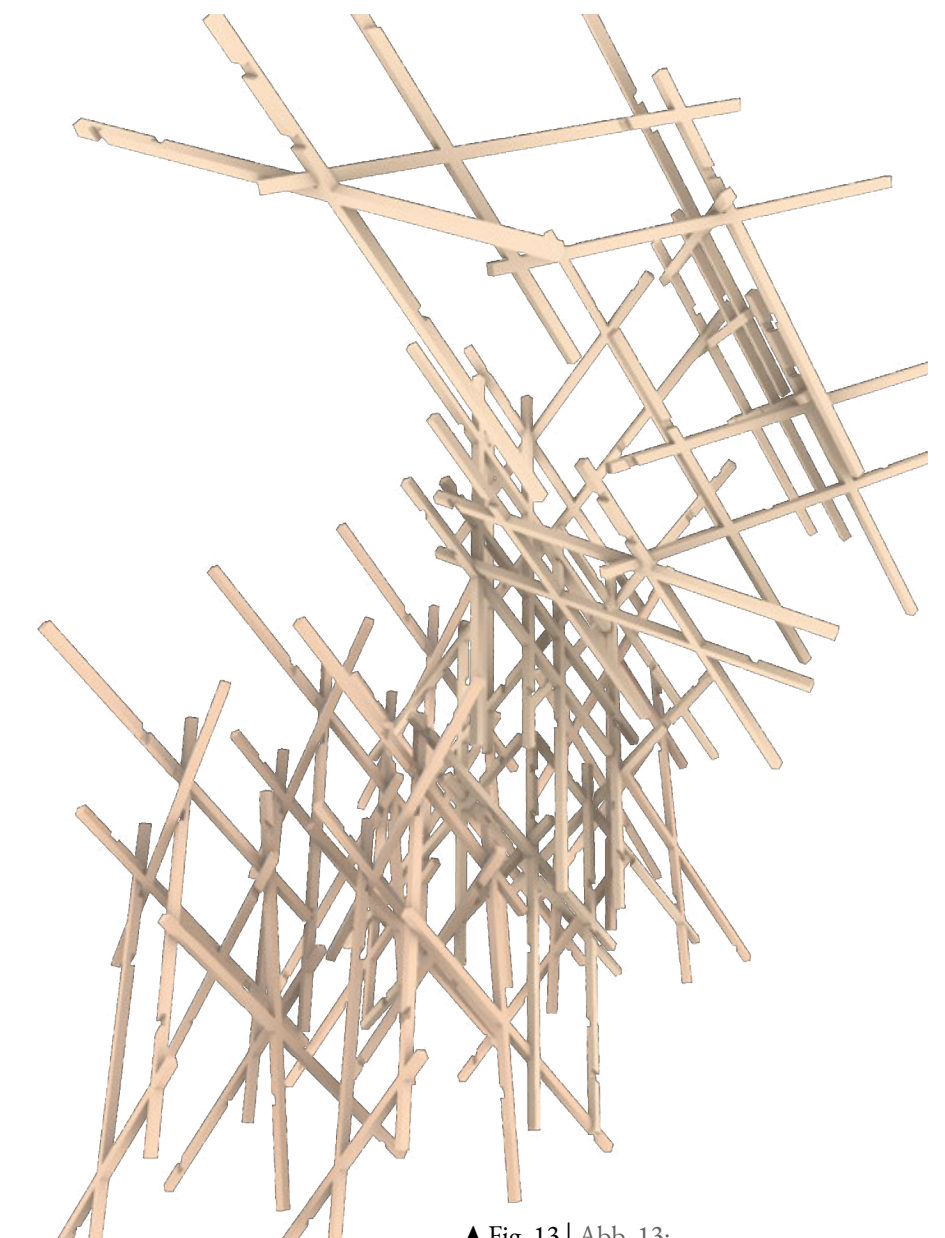

A Fig. 13| Abb. 13:

A combination of the stacking system (in the bottom area of the structure) and the versatile system (in the top area of the structure). 


\section{[2.1] INTERLOCKING SPACES : GEOMETRY}

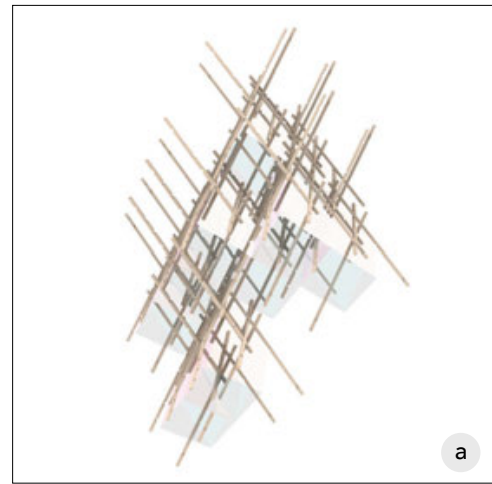

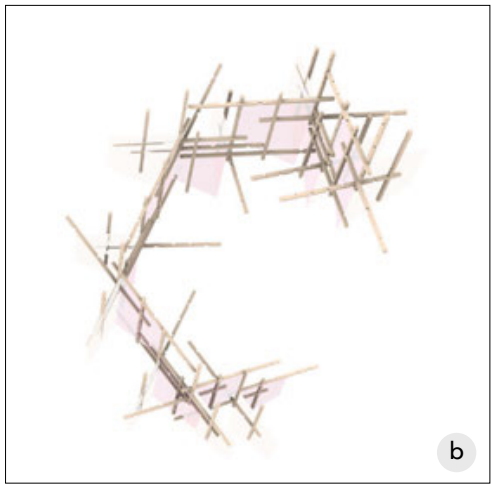

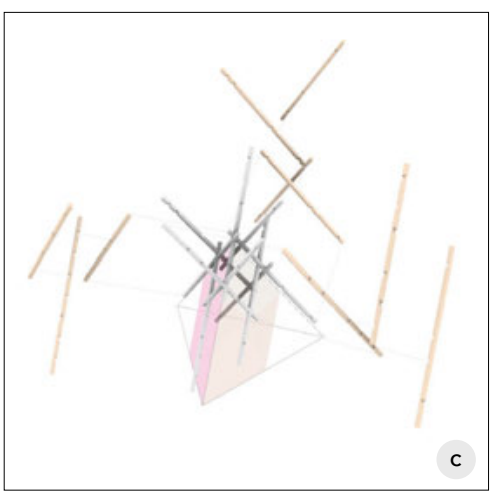

$\Delta$ Figs. 14a-c | Abb. 14a-c:

The two systems merged together into a new system that can form both linear arrays (stacking) (a) and angled arrays (b) by using ten types of beams that can be combined into two different modules (c) which can be aggregated into larger structures.

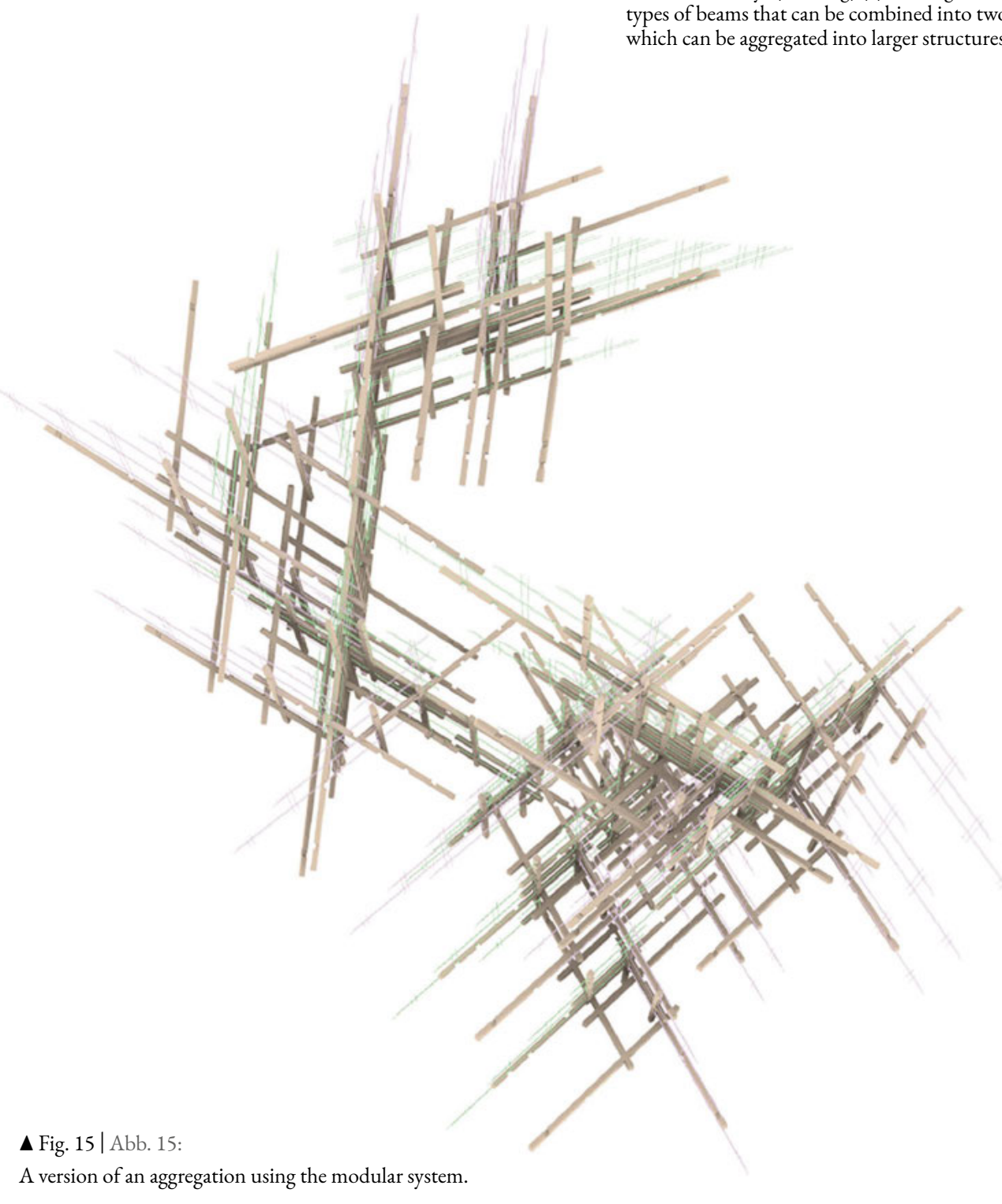



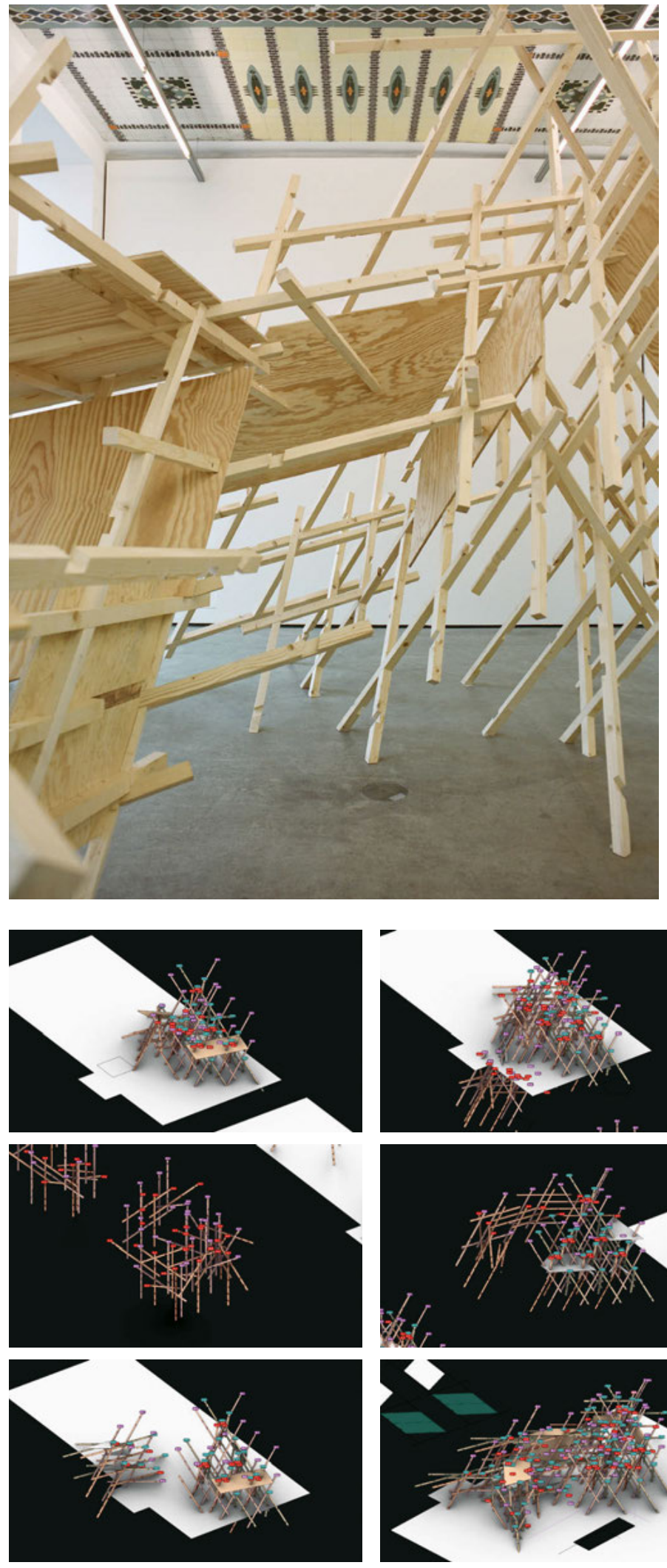
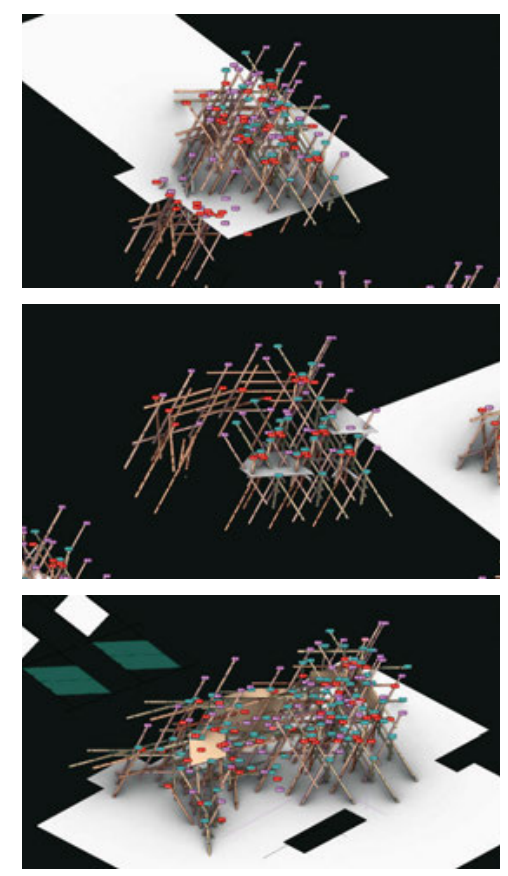

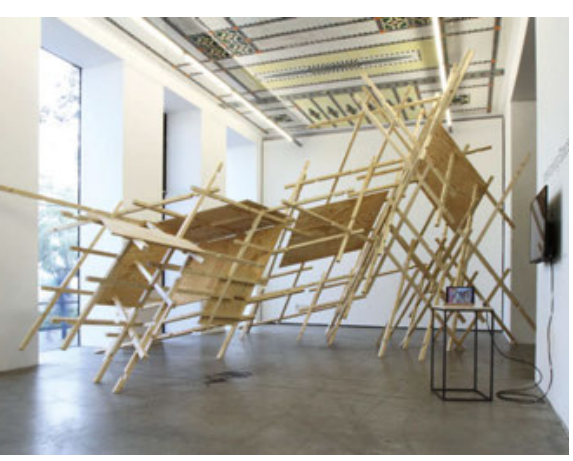

४ $\Delta$ Fig. 16 | Abb. 16

IS-2 installation for the Conceptual Joining show at AIL, Vienna, 2019.

Photo $\odot$ Zara Pfeifer (left)

V Fig. 17 | Abb. 17:

Studies of different possible configurations of the $I S-2$ system.
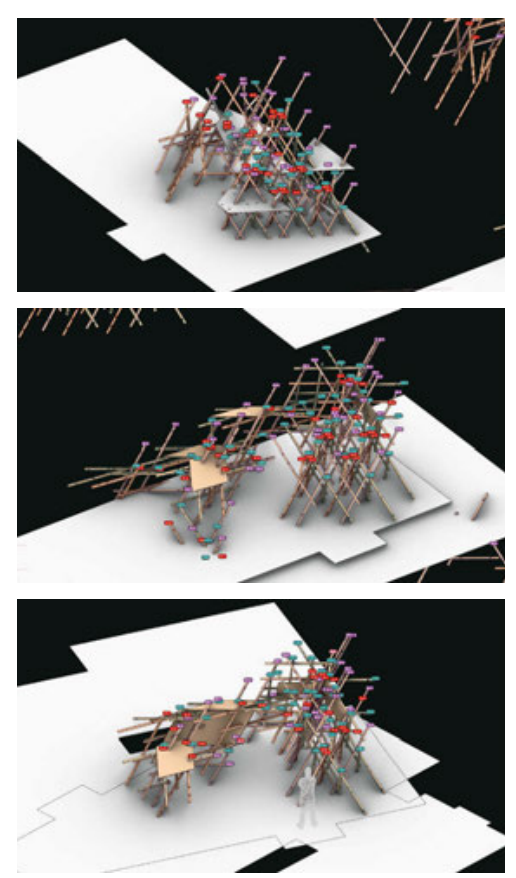
layer of design flexibility allowing for local modifications. In this way, for example, the structure could be stabilized locally, which was especially helpful at the boundary conditions where the structure was less dense and thus more ductile (Figs. 18a+b).

Furthermore, the soft wood and the simple joints would enable further ad hoc alterations in the buildup process.

\section{SPECULATION}

Whilst the table models were designed for a concrete usage, the larger installations referred to possible inhabitations on a more general and abstract level (Fig. 19). Especially $I S-2$ demonstrates the versatility of a flexible (timber construction) design system based on Kigumi principles.

In further developments, the selection of structural members could be expanded to include elements with larger spans and cross sections to accommodate larger-scale architectural activations, eventually becoming a comprehensive building construction system. Picking up the concept of a 'diffuse functionality' $\nearrow^{21}$ as a result of mediating geometric and structural constraints with functionality, the assemblies formed by this system provide usability merely as approximations (Fig. 20).

This ambivalent condition of 'more or less' binds the architectural environments to the physical reality of a joinery-based material practice.

A strong presence of 'differentness' is inherent to these structures, which aims at inviting users to a dialogue, inducing a process of inhabitation rather than adapting to predefined standard requirements. modularen Systems. Mit einigen Einschränkungen konnten diese Elemente unabhängig von ihrer vorgesehenen relativen Position neu positioniert oder hinzugefügt werden, was eine zusätzliche Ebene der Designflexibilität darstellte und lokale Modifikationen ermöglichte. Auf diese Weise konnte zum Beispiel die Struktur lokal stabilisiert werden, was besonders an den Rändern hilfreich war, wo die Struktur weniger dicht und damit duktiler war (Abb. 18a+b).

Darüber hinaus würden das weiche Holz und die einfachen Details weitere Ad-hoc-Änderungen im Aufbauprozess ermöglichen.

\section{SPEKULATIONEN}

Während die Tischmodelle für eine konkrete Nutzung konzipiert waren, verwiesen die größeren Installationen auf mögliche Bespielungen auf einer allgemeineren und abstrakteren Ebene (Abb. 19). Insbesondere bei $I S$-2 wurde die Vielseitigkeit eines flexiblen Konstruktionssystems sichtbar, das auf Kigumi-Prinzipien basiert.

In weiteren Entwicklungen könnte die Palette der Bauteile um Elemente mit größeren Spannweiten und Querschnitten erweitert werden, um architektonische Aktivierungen im größeren Maßstab zu ermöglichen und so ein umfassendes Baukonstruktionssystem zu etablieren. Das Konzept einer ,diffusen Funktionalität $\nearrow^{\mathbf{2 1}}$ aufgreifend, die sich aus der Vermittlung zwischen geometrischen und strukturellen Zwängen und einer Funktionalität ergibt, bieten die durch dieses System gebildeten Ensembles eine Nutzbarkeit lediglich als Annäherung an (Abb. 20).

Dieser ambivalente Zustand des ,mehr oder weniger ${ }^{`}$ bindet die architektonischen Umgebungen an die physische Realität einer Materialisierung.

Diesen Strukturen ist eine starke Präsenz der ,Andersartigkeit ${ }^{`}$ inhärent, die darauf abzielt, Nutzer*innen zum Dialog einzuladen und dadurch einen Prozess des Aneignens zu bewirken, anstatt sich an vordefinierte Standardanforderungen anzupassen. Dies führt zu einer anderen, einladenderen Art der Vielseitigkeit in der Architektur im Vergleich zu konventionellen, utilitaristischen Modulsystemen. 


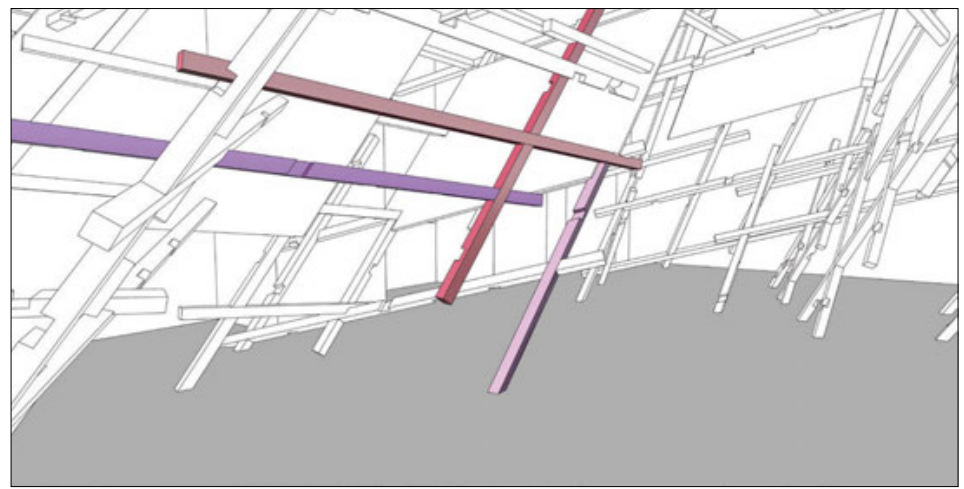

$\Delta$ Fig. 18a | Abb. 18a:

A part of the structure $I S-2$ as it was planned in the digital model turned out to be too weak in the realization.

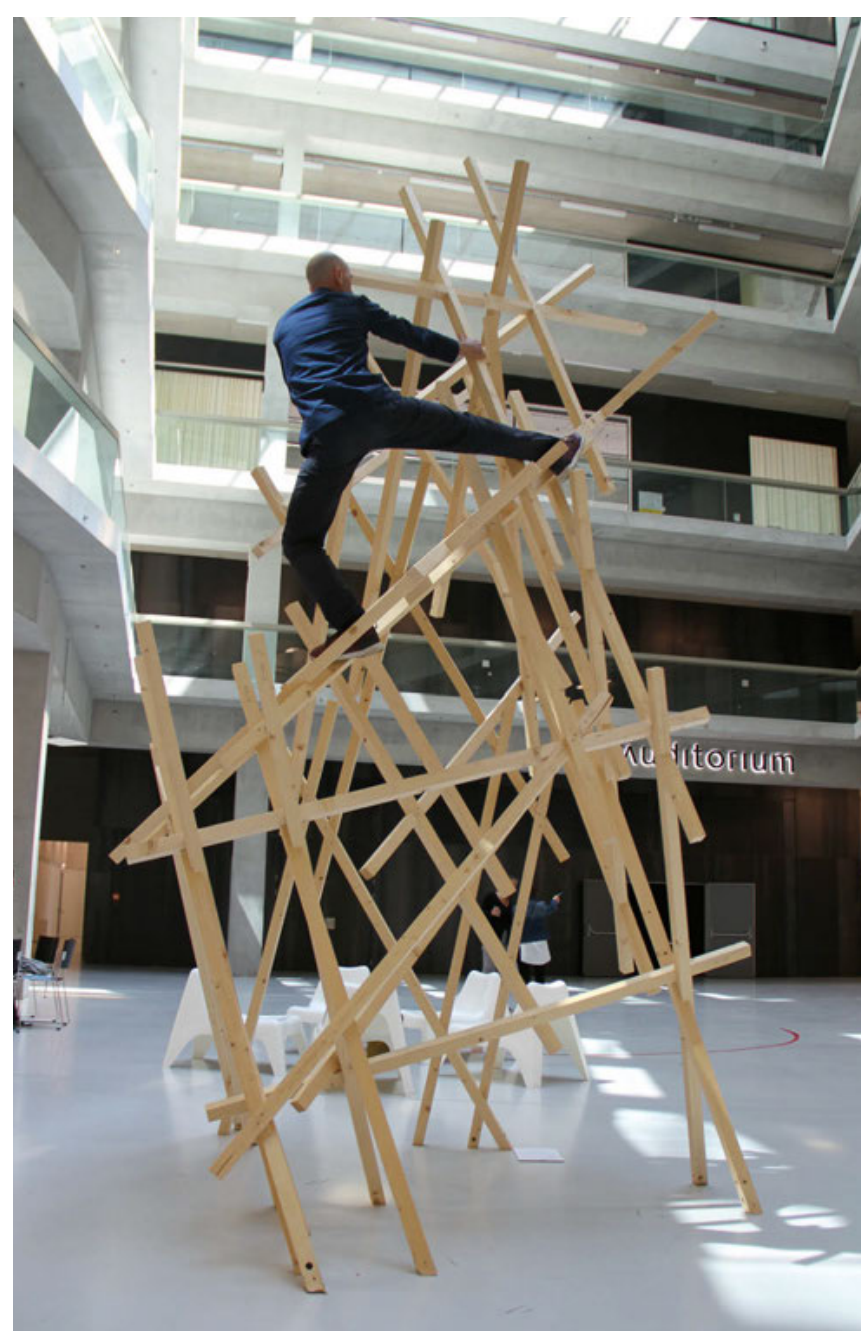

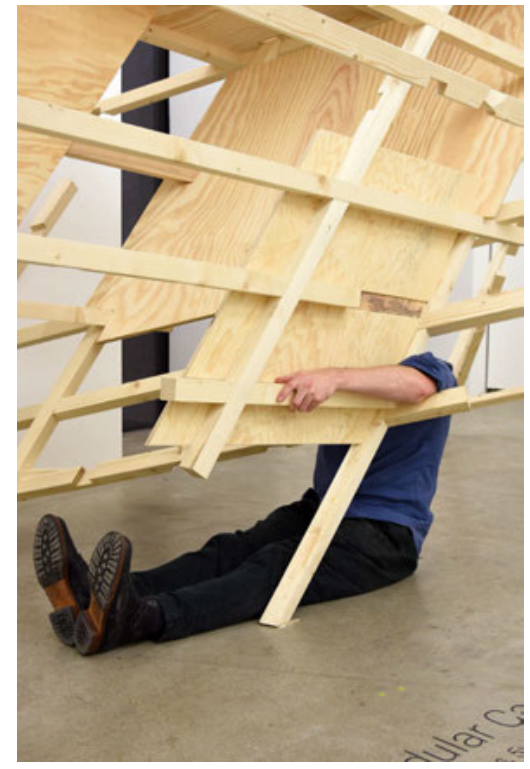

\ Fig. 18b | Abb. 18b:

A plywood panel and a beam were added in the build-up process to improve stability locally.

Photo $\odot$ Zara Pfeifer

४ Fig. 19| Abb. 19:

Performance artist Daniel Aschwanden interacting with IS-1 at the atrium of the University of Applied Arts Vienna, 2019.

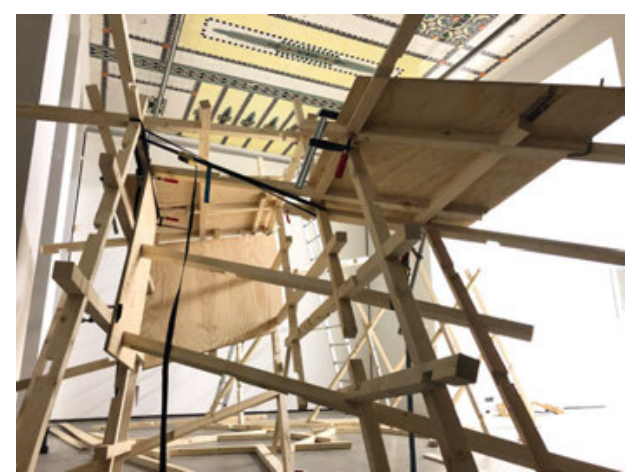

A Fig. $20 \mid$ Abb. 20:

During the construction of $I S-2$ a constellation of beams and panels frame an enclosed space and appear as an unfinished building envelope. 
